\title{
The Distinction Between Carbonate Cement and Internal Sediment in Quaternary Gravels: A Combined Field, Petrographic, and Stable Isotope Study from Northern Switzerland
}

\author{
Dominik Letsch ${ }^{1}$ \\ ${ }^{1}$ Department of Earth Sciences, ETH Zurich, Sonneggstrasse 5, CH-8092 Zürich, Switzerland \\ Correspondence: Dominik Letsch, Department of Earth Sciences, ETH Zurich, Sonneggstrasse 5, CH-8092 \\ Zürich, Switzerland. Tel: 41-443-912-066. E-mail: dletsch@ethz.ch
}

Received: December 3, 2013 Accepted: December 25, 2013 Online Published: December 30, 2013

doi:10.5539/esr.v3n1p56

URL: http://dx.doi.org/10.5539/esr.v3n1p56

\begin{abstract}
Quaternary glacial gravels are often partly cemented by carbonates, and comparable cements are also known from pre-Quaternary glacigenic rock sections. These cemented zones are of importance e.g. for applied geology or paleoclimate studies but have hitherto not been studied systematically. This article reports examples from the Alpine foreland of Northern Switzerland. It is based on geotechnical reports, field observations, petrographic and stable isotope analyses. It will be shown that carbonate cements in glacial gravel are of heterogeneous origin and that many of them should rather be considered as cemented internal sediment (i.e., sediment which infiltrated the gravel skeleton after deposition) the source of which is assumed to be the fine suspended fraction of glacier meltwater. This paper presents descriptive, petrographic, and geochemical criteria to distinguish between such cemented internal sediment and true cements, and develops genetic models to account for both the development of internal sediment and of true cements. It is suggested that the use of these models will help to better predict the spatial geometry of cemented zones in glacial gravel. Finally, we will discuss some consequences for the study of pre-Quaternary glacigenic deposits.
\end{abstract}

Keywords: carbonate cement, gravel, glacigenic rocks, stable isotopes, applied geology, internal sediment

\section{Introduction}

Vast continental areas are covered with unlithified Quaternary sediments which were deposited by glaciers and glacier-fed streams during the Pleistocene (tills, gravel etc.). As many urban areas e.g. in Europe and Northern America are located in such formerly ice-covered regions, knowledge about the internal structure, genesis, and geotechnical properties of Quaternary deposits is of paramount importance for applied geology. Even though many of these deposits are overconsolidated due to past glacier overburden, they often lack of any cementation. However, partly cemented Quaternary glacial sediments have been described both from arctic (Swett, 1974), and more temperate, but formerly ice-covered areas (Knight, 1998). The examples described by these authors are carbonate concretions of limited spatial extent (up to some m) in sandy glacial outwash deposits. Quantitatively more important is the patchy occurrence of carbonate "cemented" zones in glacial gravel (Aber, 1979; Selleck \& Baran, 2003). Despite its importance for applied geology (e.g., gravel exploitation, underground excavations, stability of natural cliffs etc.), almost no systematic studies on this topic exist so far (but see Elbracht, 2010). Especially, it would be desirable for the engineering geologist to be able to predict the spatial extension of cemented zones in otherwise loose sediment. In the sparse literature and among applied geologists, contradictory rules of thumb concerning this question are encountered (Aber, 1979; Paxton \& Martin, 1980). As all of these studies were exclusively concerned with observations made in natural and artificial outcrops, the question of how deep cementation may reach could not be addressed sufficiently.

The present study tries to partly fill this gap in our understanding of early diagenesis in coarse clastic sediments in the glacial environment. It is based on unpublished geotechnical reports, field observations in both natural and artificial outcrops, investigation of drill cores, microfacies analysis, and stable isotope geochemical investigations. We try to present criteria for distinguishing between two types of pore space-filling carbonate matter in glacial gravel which are both described as "cement" in geotechnical reports. As will be demonstrated below, many of these carbonates are not cements in the strict sedimentological sense (i.e., chemical 
precipitations) but secondary infiltrations (internal sediments sensu Dunham, 1969) which have been later cemented. True cements do also occur in Quaternary glacial gravel, but their spatial distribution and their petrographic, and geochemical characteristics are different from internal carbonate sediments. In the following, we will therefore use the genetically neutral term "carbonate putty" for all kinds of fine grained carbonates of unclear origin that occur in the pore space of gravel and that give coherence to the latter. For obvious cements in the strict sense we will retain the term cement. If the distinction between internal sediment and cement is properly made, many of the existing contradictions in the various concepts on the spatial distribution of "cemented" zones in glacial gravel can be removed. Furthermore, we will present possible genetic models for the origin of both carbonate putty and true cements, and will discuss means to discriminate between internal carbonate sediment and true cements in glacial deposits. The latter point is of importance for pre-Quaternary, completely lithified, glacial deposits, where it is a matter of some debate to which degree carbonates associated with tillites are of detrital, early or late diagenetic origin. Some consequences for pre-Quaternary glacigenic rocks will be discussed in the final chapter.

The examples treated in this paper are all from the wider Zurich area in northern Switzerland (Figure 1). Zurich lies in the Alpine foreland basin which is a low lying plateau with a smooth topography underlain by Tertiary clastic rocks (the Molasse) which represent the erosional detritus of the Alps. The Alpine foreland is bordered by the highly elevated Alpine border chains to the South (Mesozoic carbonates) and the less elevated Folded Jura mountain chain (Mesozoic carbonates) and the crystalline Black Forest Massif to the North. During the Quaternary, Alpine glaciers advanced several times into the Alpine foreland and once covered almost the whole part of it (most extensive glaciation, Figure 1). During these various glaciations, glaciers not only carved out overdeepened valleys which are today often occupied by lakes and lacustrine sediment packages, but also deposited large amounts of alpine detritus (tills and gravel).

\section{Methods}

The spatial distribution of carbonate putty and cement on a macroscopic scale was studied in natural and artificial outcrops, and in drill cores. Additionally, unpublished drill core descriptions from several geological engineering companies have been consulted. For the microscopic view, thin-sections $(30 \mu \mathrm{m})$ were studied with a petrographic microscope. Cut and polished sections were studied under the binocular microscope and with the aid of a hand-lens. Stable oxygen and carbon isotope measurements have been carried out in the Stable Isotope Laboratory of the Department of Earth Sciences at ETH Zurich. Carbonate powder has been drilled with a diamond-coated micro-drilling device. $300 \mu \mathrm{g}$ of each powder sample were reacted with orthophosphoric acid in an automated $\mathrm{CO}_{2}$-preparation device which was coupled to a MAT 253 Thermo-Fischer Finnigan Gas bench mass spectrometer. $\delta^{13} \mathrm{C}$ and $\delta^{18} \mathrm{O}$ per mil (\%o) values relative to the Vienna Pee Dee Belemnite (VPDB) standard have been calculated from the measured ${ }^{13} \mathrm{C} /{ }^{12} \mathrm{C}$ and ${ }^{18} \mathrm{O} /{ }^{16} \mathrm{O}$ ratios. Repeated measurements of a carbonate laboratory standard gave precisions of $0.06 \%$ and $0.08 \%$ for $\delta^{13} \mathrm{C}$ and $\delta^{18} \mathrm{O}$, respectively.

\section{Sampling Sites and Drill Core Localities}

We sampled seven gravel deposits for petrographic and stable isotope analysis (Figure 1). We also sampled some freshwater tufa deposits and pedogenic carbonate nodules for stable isotope analysis.

\subsection{Menzingen Gravel Pit}

In the Menzingen gravel pit, a gravel sequence of some $20 \mathrm{~m}$ thickness is exposed. The gravel is fine grained and well sorted but contains powdery carbonate and clay films coating the pebbles. The basal part of this gravel which is underlain by a till layer is partly water saturated and exhibits an intense cementation. From this zone we took our samples. As the Menzingen gravel is overlain by moraine ridges of the last glaciation (Marine Isotope Stage MIS 2), we infer a pre-MIS 2 age. However, the close genetic connection to the overlying till implies an age not much older than MIS 2.

\subsection{Eschenberg-Chüeferbuck Gravel Pit}

In the former gravel pit Chüeferbuck a well preserved Late last glacial glaciolacustrine Gilbert-type delta is exposed (Figure 2). We sampled both carbonate putty from the finer grained foreset and from the coarser grained topset layers. The exact age of this delta is not known, but it belongs into Late MIS 2.

\subsection{Kloten-Dorfnest, Hagenholz Railway Tunnel, and Drill Core Seegräben}

Near Zurich airport a drilling campaign was carried out in 2012 for a new road construction. The underground geology of this area was rather well known due to extensive drilling and underground excavation for a nearby railroad tunnel in the late 1970s (Figure 3). From the 2012 drill cores we took samples of carbonate putty from a pre-MIS2 glacial gravel for petrographic and stable isotope analysis. As we knew from the tunnel profile, the 
sampled gravel complex is severely deformed by glacial tectonics and contains layers of glacial lake deposits. It is overlain by till of the last glaciation. The sampled gravel complex can be followed some $20 \mathrm{~km}$ towards the SE to the village of Seegräben (Figure 1), from where we report a drill core description in Figure 4. According to Graf (2009) this till-related, fluvioglacial gravel complex was deposited during a Middle Pleistocene (200 to 300 ka) glacier advance.

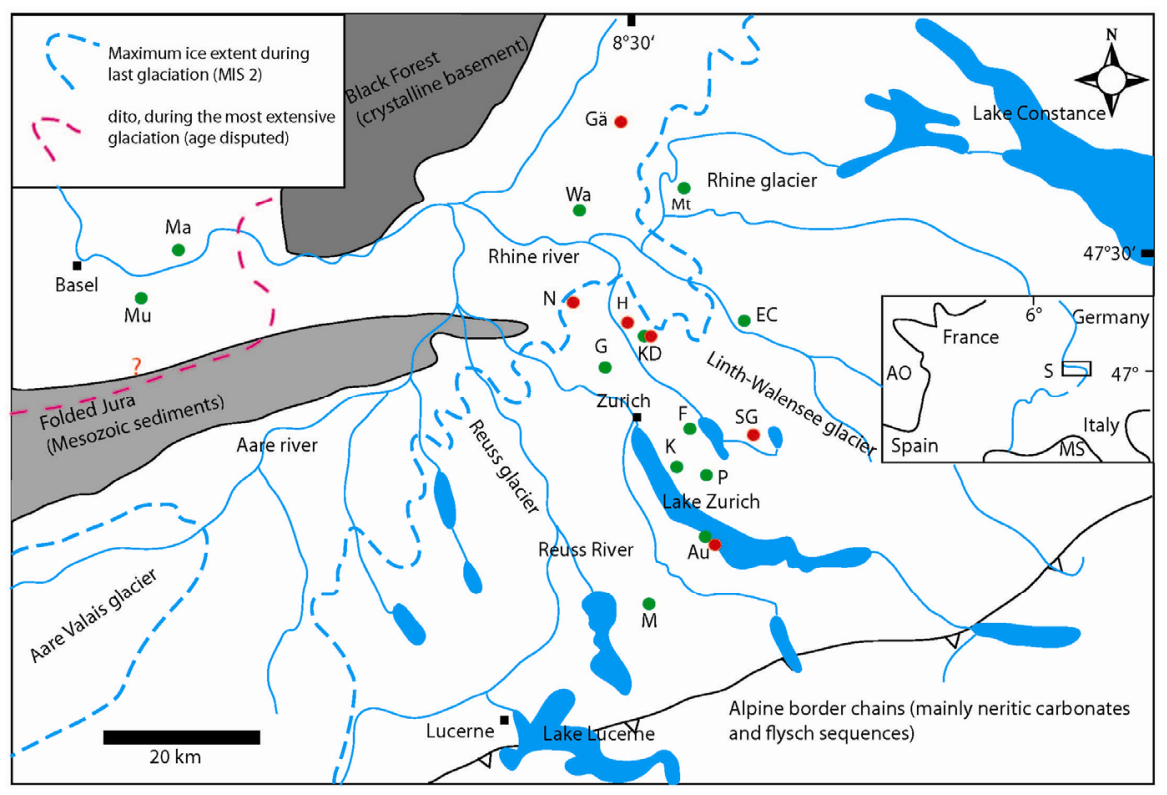

Figure 1. Geographic and geologic sketch map of the study area. For the overall location in Western Europe, see the small inset map. Ice extents during the last (light blue) and during the biggest Quaternary glaciation (red) are drawn after Graf (2009). Sampling sites are indicated with green dots. Gravel sites: M: Menzingen; $\mathrm{Au}: \mathrm{Au}$

peninsula; K: Küsnacht; G: Gubrist; EC: Eschenberg Chüeferbuck; Ma/Mu: Markhof/Muttenz; Wa:

Wasterkingen; Mt: Marthalen. Freshwater tufa and pedogenic carbonate nodules sites: F: Fällanden; P: Pfannenstiel; G: Gubrist; K: Küsnacht. Drill core and tunnel locations are shown with red dots. Gä: Gächlingen; N: Neerach; H: Hagenholz tunnel; KD: Kloten-Dorfnest; SG: Seegräben

\subsection{Au Peninsula}

The Au peninsula is a rocky drumlin which protrudes into Lake Zurich composed of overconsolidated glacial lake deposits, till, and well cemented but badly sorted gravel. It has not been dated so far but must be older as the last glaciation (MIS 2). The gravel contains sandy lenses and may exhibit crude bedding. From this we infer a glaciofluvial origin close to a glacier which later overrode the gravel and plastered some till onto it. The gravel was sampled in outcrops and a nearby drill core is described schematically in Figure 4.

\subsection{Küsnacht Valley}

The Küsnacht valley is a local tributary to the Lake Zurich valley and is incised into the Molasse bedrock. In its middle part it cuts through an older pre-MIS 2 valley that runs approximately at right angles to the modern valley and is filled with a complex glaciolacustrine to glaciofluvial sediment package (Letsch, 2012). This package can be divided into several lithofacies which document a fossil ice-marginal delta sequence ranging from proximal flow tills and poorly sorted glaciofluvial gravel, over coarse grained delta deposits (glaciolacustrine gravel) to sandy lake floor deposits. The latter contain $\mathrm{cm}$ thick layers of fine grained carbonate. The exact age of this fossil delta complex is not known; however, as it is overlain by moraines of the last glacial maximum, it must at least be pre-MIS 2.

\subsection{Gubrist Gravel Pit}

On top of the Gubrist hill north of Zurich, a well sorted glaciofluvial gravel is exposed which is genetically linked to an overlying lodgement till unit. Due to its height some $200 \mathrm{~m}$ above the valley floor, a high (at least Mid-Pleistocene i.e. more than $600 \mathrm{ka}$ ) age has generally been assigned to this and other highly elevated gravel bodies (Graf, 1993). 


\subsection{Gravel Pit Wasterkingen}

The former gravel pit at Wasterkingen exposes a gravel sequence of some $20 \mathrm{~m}$ overlain by lodgement till. The gravel is divided in two units with the lower exhibiting signs of intense weathering. The upper is fresher and contains abundant micritc putty and, especially on joint surfaces, coarse crystalline calcite cement. This upper gravel body has been sampled for petrographic analysis. As Wasterkingen lies outside the maximum ice extension of the last glaciation (Figure 1), the lodgement till on top of the sequence must be older than MIS 2. It may correspond to the most extensive glaciation and the upper gravel just underneath may be related to the initial phases of this glaciation.

\subsection{Markhof, Muttenz, Marthalen: Rhine Gravel}

These well sorted, sandy, occasionally through-crossbedded gravel bodies constituting fluvial terraces some $\mathrm{m}$ above the present Rhine river at the Markhof and Muttenz sites were dated by various methods as Middle to Late MIS 2 (20 to $10 \mathrm{ka}$; Kock et al., 2009). They were deposited in an area which has never been covered by Alpine glaciers, so any direct glacial influence on cementation can be excluded. We did not sample them ourselves but used the stable isotope data reported by Kock et al. (2009). Gravel of similar age and composition was studied in the Marthalen gravel pit. Even though this locality is inside the maximum ice extent of the last glaciation, the gravel seems to be deposited during the receding phase of MIS 2 and was therefore not directly affected by glacial activity.

\subsection{Drill Cores Gächlingen and Neerach}

Both cores were taken from late MIS 2 gravel bodies of purely fluvial origin which were deposited outside or near to the maximum extent of the MIS 2 glaciers.

\subsection{Pedogenic Carbonate Nodules and Freshwater Tufa}

Pedogenic carbonate nodules have been sampled from the till layer just overlying the Gubrist gravel. The till is a grey mixture of sandy and silty clay with embedded pebbles of Alpine origin. It is overconsolidated and can be best interpreted as a basal lodgement till of presumably pre-MIS 2 age. It contains spherical, white and chalky nodules of up to some $\mathrm{cm}$ diameter. Two of these have been analyzed for stable isotopes. Freshwater tufa has been sampled from several small cones which build at springs in creeks all around Zurich (Figure 1). They are normally of very porous appearance but can occasionally attain a dense and hard crust-like appearance.

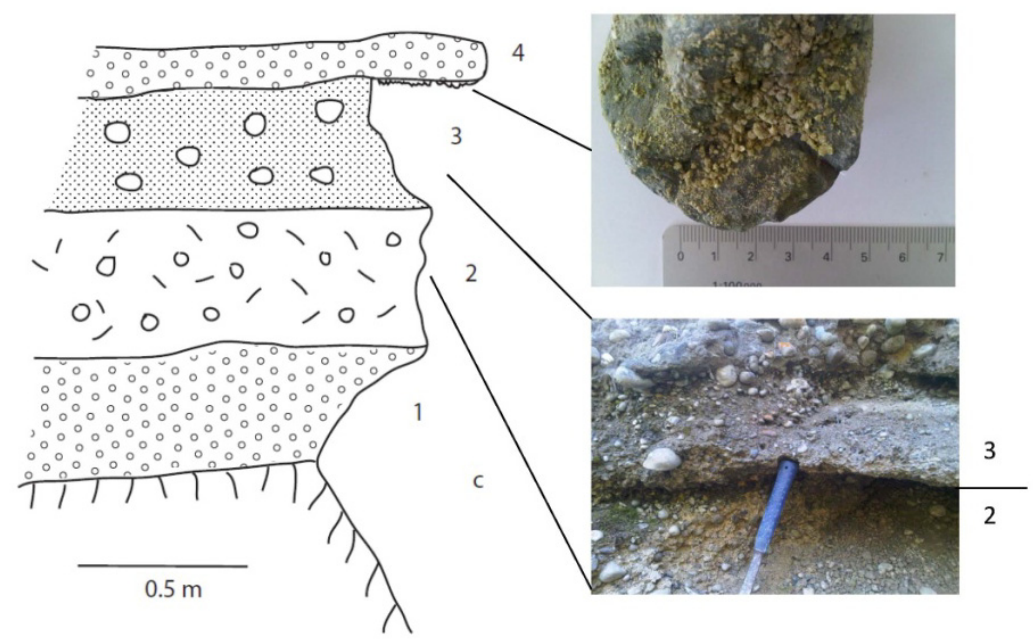

Figure 2. Outcrop sketch from the Eschenberg-Chüeferbuck gravel pit. The view is parallel to the dip of the

layers which are part of a Gilbert-type delta foreset complex. 1: sandy gravel, unlithified, no putty; 2: fine grained gravel, no sand but abundant carbonate putty; 3: matrix supported, sandy gravel, unlithified; 4: coarse topset gravel, some putty and abundant gravitational cement on pebble undersides (inset photo)

\section{Results and Interpretations}

\subsection{Field Observations}

From the purely descriptive point of view, two basic type of carbonate putty/cement in Quaternary gravel could 
readily be distinguished in the field.

\subsubsection{Fine Grained Putty}

Yellowish "fine grained" (i.e. no individual crystals can be distinguished with the naked eye), sometimes powdery, carbonate putty which develops either on pebble undersides (forming sometimes microstalactites, cf. Aber, 1979) or fills the pore space in a very irregular manner, is a common feature of Quaternary gravels. Most striking in the field is the recognition that this fine grained putty most often occurs in gravel bodies or in individual layers which lack any substantial amount of sandy matrix (open framework gravel).

Figure 2 depicts an outcrop from the glaciolacustrine Chüeferbuck delta and may serve as an example to illustrate this. The matrix-supported layer No. 3 is densely packed but does not exhibit any cementation or any other carbonate putty i.e. the sandy matrix is clean and not silty or clayey. The underlying open framework gravel (No. 2) contains fine grained carbonate putty which binds the pebbles together and gives the gravel a rock like appearance. As we know of no sedimentary process in a delta environment which deposits an extremely bimodal (pebbles and silt/clay but no intermediate grades) sediment as layer No. 2 in one instance, we conclude that the fine grained putty is either a pure cement, or a later cemented, fine grained internal sediment which infiltrated the initially very porous gravel skeleton. The lack of cementation in layer Nr. 3 could be taken as evidence that cementation of the underlying layer is determined by the occurrence of pre-existing fine grained internal sediment.

Further evidence for this conjecture is provided by the fossil delta complex in the Küsnacht valley. Fine to coarse grained but sand-poor gravels of the proximal lithofacies are thoroughly bound together by a sometimes rather hard, sometimes rather friable, yellowish fine grained putty (Figure 5A). The distribution of the putty seems rather irregular: it often coats individual clasts with a layer of uneven thickness but may also project into the pore space. In some instances, a thin veneer of small calcite crystals (some mm in length) covers the micrite putty. In the distal sandy facies of the delta complex, friable to hard sandstones can be observed. They contain elongated concretions (typical for cementation under phreatic conditions, see Elbracht, 2010), and thin layers (up to $1 \mathrm{~cm}$ thickness) composed of material which resembles the fine grained putty of the proximal lithofacies and which are contorted and folded in a slump-like manner (Figure 5B). Thus, we interpret the field observations as follows. Clay to silt sized, mostly carbonate detritus infiltrated the proximal lithofacies of the delta complex. This happened shortly after deposition of the gravel as the same carbonate detritus was also sedimented in the distal equivalents of the delta gravel (the sandy lake bottom sediments), where it formed slumps. Thus, an explanation as pure cement can be excluded for the fine grained putty. That it forms today a hard and rocklike cement, must therefore be attributed to a later cementation phase under phreatic conditions whose traces are also found in the thin calcite veneers in the coarse proximal facies and in the concretions of the distal sand facies.

In the Wasterkingen gravel pit, the upper gravel body exhibits patchy zones which are enriched in yellowish to light brown micrite putty (Figures 6D and 6E). This putty gets more abundant towards the top of the gravel body where it is overlain by a till layer.

A very distinct type of fine grained putty is frequently found in fluvial gravel which is not directly related to glacial processes. Kock et al. (2009) described fine grained and irregular calcite crusts which developed on pebble undersides and along grain contacts in the gravels from Markhof and Muttenz. Thus these crusts resemble the gravitational cement of Müller (1971) and the meniscus cement of Dunham (1971), respectively. Similar crusts were sampled for the present study in the Marthalen gravel pit where they occur in otherwise totally loose gravel (Figure 6F), and in the topset layers of the Chüeferbuck delta complex (Figure 2).

\subsubsection{Sparitic Cement}

The spatial distribution of sparitic cement is more restricted and more regular in outcrops than it is the case for the above described fine grained putty. A good example provides the Menzingen gravel pit, where well developed isopachous calcite cement (Figure 6A) does only occur in the basal part of the section where the gravel is water-saturated due to an underlying impermeable till layer. The calcite cements overgrow a light brown and powdery matter which covers the pebbles and which does also occur above the local groundwater table. Both, cement and powdery matter underneath have been analyzed for stable isotopes.

Unpublished reports on gravel exploitation in gravel pits of the greater Zurich area often mentioned similar cementation patterns: coarse calcite cement does only occur where the gravel pits extend into the groundwater-saturated realm. Some reports also mention a possible connection between cementation and the zone in which the groundwater table oscillates i.e. the zone which repeatedly changes from vadose to phreatic conditions. 
A different spatial geometry of cement was observed in the upper gravel body in the Wasterkingen gravel pit. Sparitic isopachous cement (Figures 6D, 6E) was virtually restricted to zones of some $\mathrm{cm}$ width that followed open joints in the otherwise less cemented (cloudy occurrence of micrtic putty, see 4.1.1) gravel.

To sum up these observations, we conclude that gravel zones thoroughly cemented by sparitic cement seem to be restricted to areas which are, or once were, under phreatic conditions. They may occur beneath the general groundwater table, or in locally saturated zones in an otherwise vadose environment (as along the temporarily water filled joints in the Wasterkingen gravel pit).

\subsection{Observations from Tunneling and Drilling Activities}

Drill cores provide us with information on the two-dimensional distribution of zones rich in carbonate putty and cement in glacial gravel. Tunneling provides furthermore the rare occasion to study the three-dimensional aspects of this distribution. Figure 4 shows five instructive examples from drill cores and Figure 3 one of the rare, very well documented, cases where "cemented" gravel could be studied during tunneling activity. From purely visual inspection of the five logs, we can distinguish two types of two-dimensional distribution patterns of carbonate putty and/or cement.

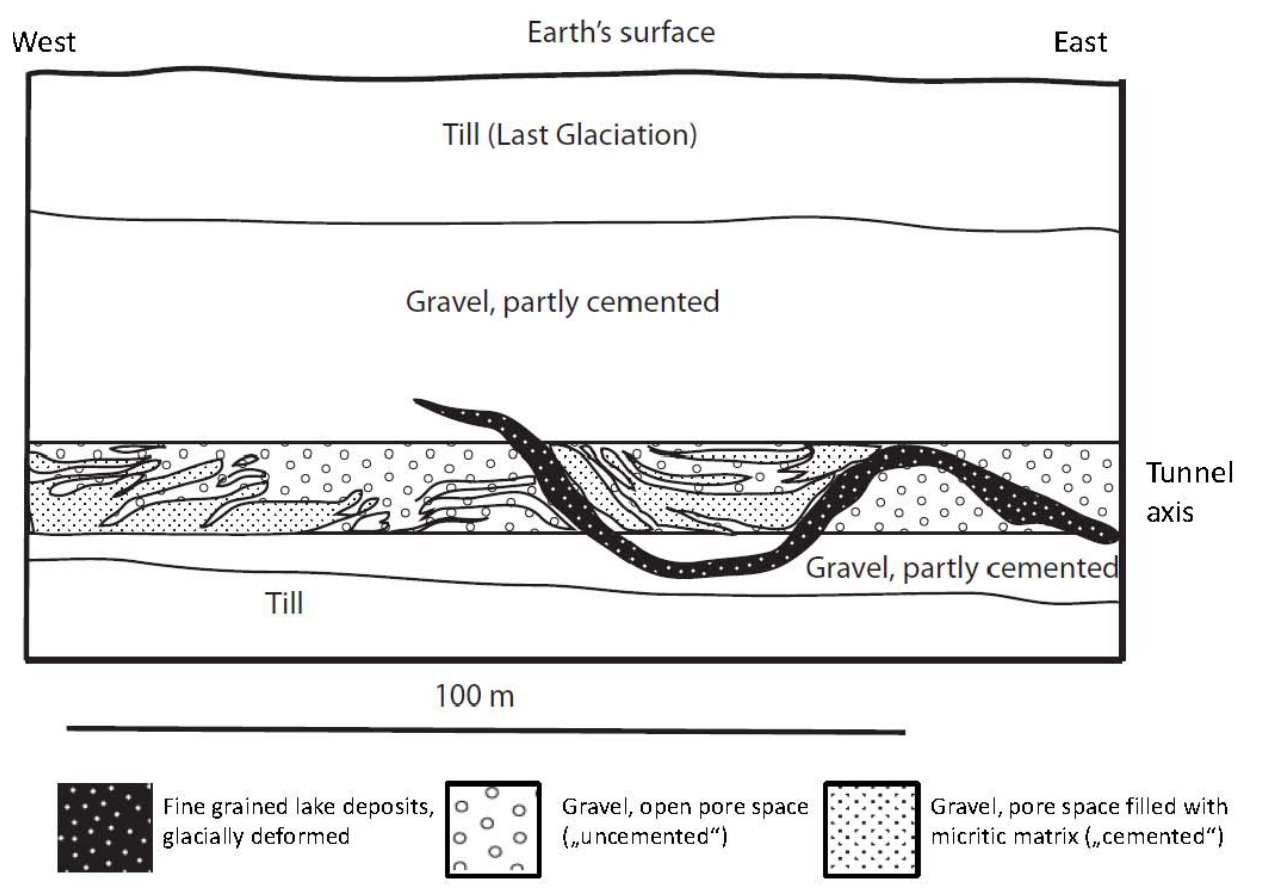

Figure 3. Lithology along the Hagenholz railway tunnel (after Longo, 1978). See text for explanation

\subsubsection{Cemented Zones Bound to Certain Layers}

The logs $\mathrm{Au}$ and Gächlingen only showed cemented zones along discrete and rather thin (generally less than 1 m) layers. Judging from the log descriptions, these layers were hardened by cement in the strict sense (sparry calcite). In the Au case, all cemented layers occur below the present groundwater table. Remarkably, the Au gravel in this drill core was generally very sandy and the cemented layers did occur both in rather clean gravel and in very sand-rich (even sand-matrix supported) layers which stands in marked contrast to the distribution pattern of fine grained putty as previously described (4.1.1). In the log from Gächlingen, cemented layers were all composed of sandy gravel. A very coarse unit in some $70 \mathrm{~m}$ depth with almost no sand was totally uncemented. Most of the cemented zones were above, some below the present-day groundwater table. It is interesting to note that the zone of groundwater oscillation (determined from repeated measurements over two decades) coincides exactly with a cemented gravel layer.

The log from Neerach does also exhibit a cemented zone which is bound to a certain horizon, however, the latter is not as thin as the examples from the two other wells. In this case, the cementation seems to be restricted to the zone which is permanently beneath the water table (phreatic). 


\subsubsection{Irregular Cemented/Putty Rich Zones}

The logs from Seegräben and Kloten-Dorfnest exhibited irregularly distributed, patchy, zones which are "cemented" with yellowish fine grained putty (Figure 5E). In the drill core from Kloten-Dorfnest, putty-rich zones did occur only sporadically. The nearby Hagenholz tunnel (Figure 3) penetrated the same gravel and demonstrated the irregular occurrence of putty rich zones. During underground excavation for this tunnel, it was virtually impossible to predict the geometry of these zones: they did not follow former groundwater tables as initially assumed as working hypothesis (Longo, 1978), but did mostly occur in layers lacking any sandy or silty matrix which corresponds well to our observations from natural outcrops. Additionally, the gravel in the Hagenholz tunnel was later subjected to glacial tectonic deformation which is well demonstrated by a folded layer of fine grained lake deposits.

In the case of Seegräben, a section of approximately $70 \mathrm{~m}$ of gravel was bound together by hard, fine grained putty. However, the putty was not bound to certain horizons but instead occurred in a patchy manner over the whole length of these $70 \mathrm{~m}$. A correlation to the groundwater table could not be identified.

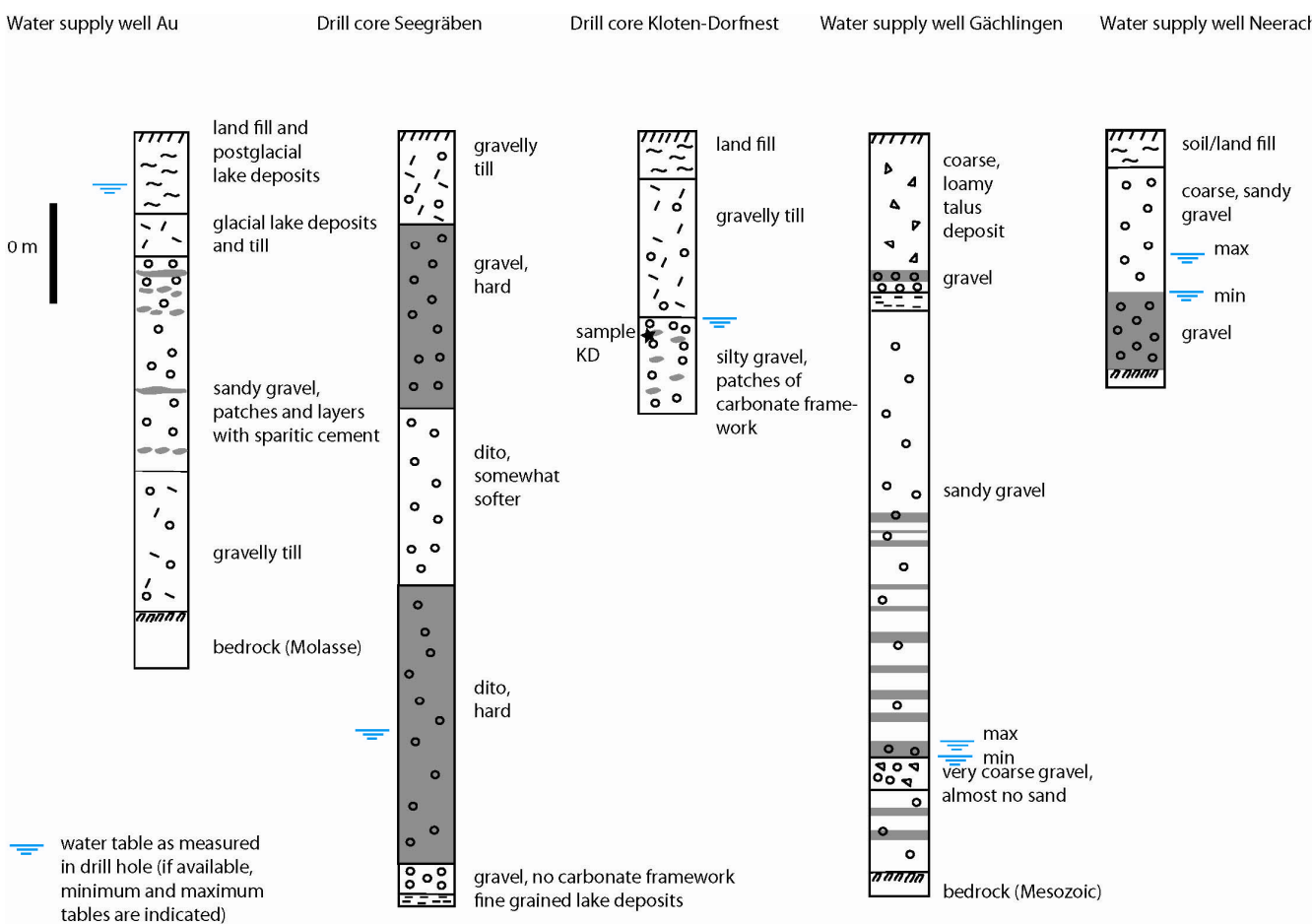

Figure 4. Simplified drill core descriptions to illustrate the different two-dimensional distribution patterns of carbonate putty/cement (indicated in grey). Redrawn after unpublished reports (1970s to today). For locations see Figure 1

\subsection{Microscopic and Mesoscopic Observations}

The two distinct types of cement/putty which could be observed in outcrops, drill cores, and underground excavations (fine grained versus sparitic) could also be identified in hand specimens, in cut and polished rock slabs, and in thin sections.

\subsubsection{Fine Grained Putty}

As described above, fine grained putty occurs in two varieties: as irregularly distributed "micritic" patches and as crusts or micro-stalactites on pebble undersides and along grain contact zones. The distinction between these two is also possible in hand specimens and in thin section. The most obvious criterion of discrimination is the grain/crystall size. The micritic patches are made up of constituents which appear as a brownish mass in thin sections (Figure 5D), thus the individual grains/crystals are smaller than the thickness of the thin-section $(30 \mu \mathrm{m})$ which is the reason for their isotropic optical behavior. This micritic groundmass does, however, contain coarser detritus (Figure 5C, F). Contrary to this, microscopic studies of micro-stalactites and related crusts (Selleck \& Baran, 2003; Kock et al., 2009) revealed that they are composed of calcite crystals which can attain dimensions 
of up to $60 \mu \mathrm{m}$. A less direct discriminating feature is the nature of internal lamination and layering. Both putty types can exhibit lamination. Kock et al. (2009) described regular dark laminae (composed of organic matter) which alternate with layers of calcite crystals in crusts on pebble undersides. Individual layers which could be observed in patchy micrite, on the other hand, are clearly due to the admixture of coarser detritus (Figures 5E, 5F). This second type of lamination is also more irregular than the supposedly biogenic laminae observed in crusts on pebble undersides. Furthermore, it shows signs of (glacio-tectonic) deformation such as folding and thrusting. These structures are the microscopic equivalents of the glacio-tectonic deformation features which were observed in the Hagenholz tunnel (Figure 2). Finally, the spatial distribution of the two putty types on a microscopic scale is different. Even though the micritic and patchy putty seems to be distributed totally irregular in the hand specimen, its microscopic distribution may exhibit some remarkable features. As shown in Figure $5 \mathrm{D}$, it may fill some pore space and may terminate against still open pore space with rather sharp and even boundaries. In some instances these boundaries are more or less horizontal and the putty fills the lower part of closed pore space domains (infill structures). Another, very peculiar feature is the occurrence of pebble contacts in zones full of micritic putty which are not filled by the putty but instead by drusy cement which must post-date the development of the putty. The spatial distribution of the crusty and micro-stalactitic putty, on the other hand, is remarkably different. It exclusively develops on pebble undersides in open-framework gravel or at pebble contacts (meniscus cement). Furthermore, its boundaries are never even and smooth but rather curved, crumbly, cone-like (stalactitic), and generally very irregular (Figure 2).

The observations just reported are interpreted as further evidence for the assumption that the micritic and patchy type of putty originated as internal sediment which infiltrated an already existing gravel skeleton. The glacio-tectonic deformation of some of these micritic putties, necessitates to assume that the putty initially was in a soft state which allowed its plastic deformation.

\subsubsection{Sparitic Cement}

Sparitic cement does exhibit two geometries. Most often it covers the rim of the pore space with acicular calcite crystals with their long axes oriented at right angles to the pore space walls (isopachous rim cement; Figures 6A, B, C). They are the result of calcite growth in freshwater under phreatic conditions (Selleck \& Baran, 2003). More rarely, blocky sparite can be observed which completely fills closed pore space domains. Figure 6C documents such a case: the contact area between two carbonate pebbles which were otherwise enveloped by micritic putty must have stayed open. In this cavity a first cement generation grew as an isopachous rim cement. Afterwards, the remaining space of the cavity was filled by coarser, more or less equant calcite crystals which do not exhibit any preferred orientation.

\subsection{Stable Isotopes}

The results of our stable isotope measurements are displayed graphically in Figure 7 and numerically in Table 1. We grouped the data into five categories. In the $\delta^{13} \mathrm{C} / \delta^{18} \mathrm{O}$ plot, the data can be divided into two realms based on the $\delta^{13} \mathrm{C}$ values. The first realm $\left(\delta^{13} \mathrm{C}<-9 \%\right)$ comprises all gravitational and sparitic cements and most freshwater tufa samples. The second realm $\left(\delta^{13} \mathrm{C}>-9 \%\right.$ ) contains all micritic putty samples and the two carbonate concretions which grew in a till layer. We did not extra distinguish in Figure 7 the data obtained from the micrite layers in the sandy facies of the fossil delta complex in the Küsnacht valley as we interpret them to consist of exactly the same material as the fine grained carbonate putty in the coarser facies of this delta complex (4.1.1). The identical isotope signatures (Table 1) do additionally justify this conjecture.

Freshwater tufa was shown to reflect the stable carbon isotope composition of the dissolved inorganic carbon (DIC) in the spring water (groundwater) from which it precipitates, i.e. even though calcite precipitation in tufa is often organically induced, it takes place according to the rules of inorganic carbonate equilibrium chemistry (Andrews et al., 1993). Equilibrium isotope fractionation effects during carbonate precipitation are temperature-dependant and affect mainly the oxygen isotope composition whereas the fractionation of carbon isotopes during chemical precipitation of carbonate under near-surface temperatures is rather minor and the fractionation factor is only weakly temperature-dependant. Hence, we can assume that the typical stable carbon isotope values of freshwater tufa of a given area are the values which one has to expect for any calcite which precipitates from groundwater in that area. The stable oxygen isotope values have to be treated with more care, as the $\delta^{18} \mathrm{O}$ of groundwater is prone to changes due to non-equilibrium processes such as evaporation. 


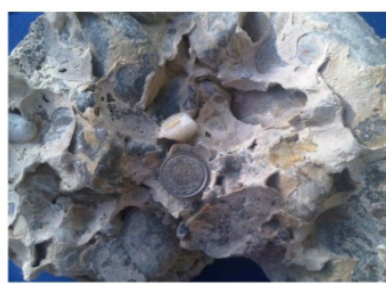

A

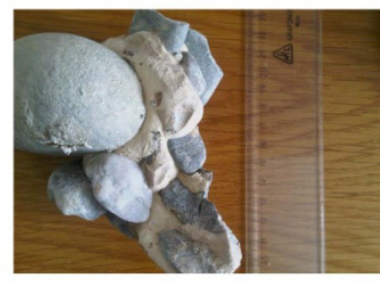

C

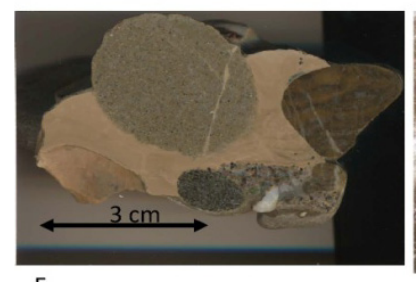

E

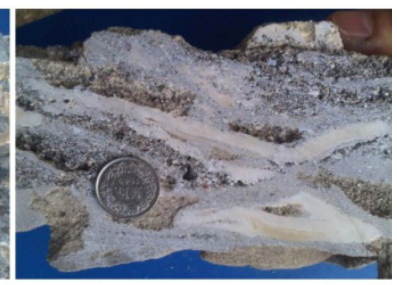

B

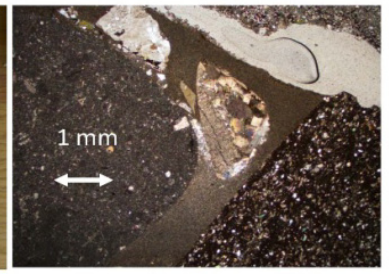

D

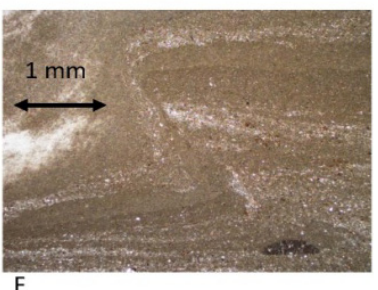

Figure 5. Examples of carbonate putty (interpreted as cemented internal sediment). A: glacial gravel from Küsnacht; B: Micrite layers in the sandy lake facies from Küsnacht; C: Putty from the Kloten-Dorfnest drill core; D: Putty (homogeneous brown mass) between four sedimentary clasts. Note the meniscus-like cement between two clasts and the open pore space above the smooth and straight boundary of the putty; from Au peninsula, thin section, crossed nicols; E: Same as C but cut and polished; note the fine lamination which is deformed; F: Same as $\mathrm{C}$ and $\mathrm{F}$ but seen in thin-section (crossed nicols): glacio-tectonic deformed internal sediment with coarser layers
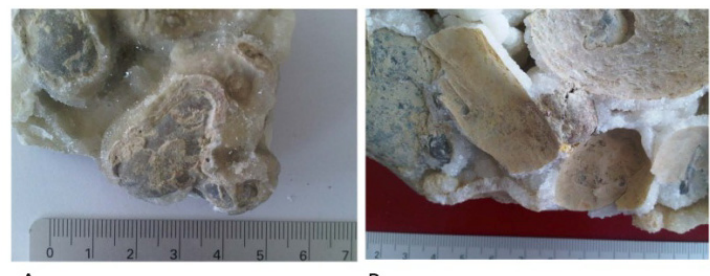

A
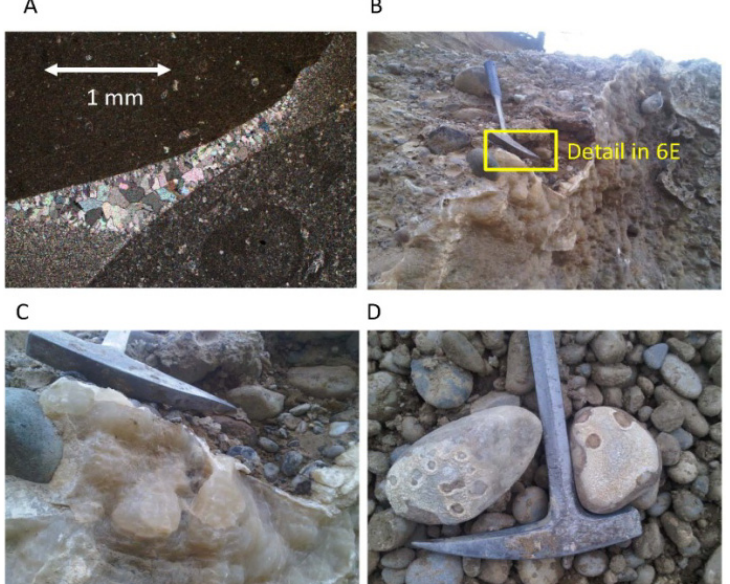

F

Figure 6. Examples of carbonate cements. A: Menzingen; B: Wasterkingen; C: Au peninsula, thin-section (crossed nicols); D/E: Wasterkingen; F: Marthalen. See text for explanation 
Table 1. Stable isotope data

\begin{tabular}{|c|c|c|c|c|}
\hline Locality & Description & $\delta^{18} \mathrm{O}(\mathrm{VPDB})$ & $\delta^{13} \mathrm{C}(\mathrm{VPDB})$ & Source \\
\hline Küsnacht & Micritic putty & -6.54 & -8.35 & Letsch (2012) \\
\hline Küsnacht & Micritic putty & -6.42 & -8.47 & Letsch (2012) \\
\hline Küsnacht & Micritic putty & -6.43 & -8.14 & Letsch (2012) \\
\hline Küsnacht & Micritic putty & -6.83 & -8.08 & Letsch (2012) \\
\hline Küsnacht & Micritic putty & -6.83 & -8.08 & Letsch (2012) \\
\hline Gubrist & Micritic putty & -8.65 & -7.64 & This paper \\
\hline Menzingen & Putty, powdery & -8.05 & -7.76 & Letsch (2012) \\
\hline Menzingen & Putty, powdery & -7.54 & -3.01 & Letsch (2012) \\
\hline Küsnacht & Micrite layer in sandy facies & -6.64 & -8.64 & Letsch (2012) \\
\hline Küsnacht & Micrite layer in sandy facies & -6.69 & -8.03 & Letsch (2012) \\
\hline Menzingen & Sparitic, isopachous cement & -7.24 & -9.76 & Letsch (2012) \\
\hline Menzingen & Sparitic, isopachous cement & -7.55 & -9.99 & Letsch (2012) \\
\hline Küsnacht & Freshwater tufa & -6.98 & -9.19 & This paper \\
\hline Fällanden & Freshwater tufa & -7.50 & -9.49 & This paper \\
\hline Küsnacht & Freshwater tufa & -8.69 & -9.90 & This paper \\
\hline Küsnacht & Freshwater tufa & -10.88 & -8.96 & This paper \\
\hline Pfannenstiel & Freshwater tufa & -7.49 & -7.80 & This paper \\
\hline Küsnacht & Freshwater tufa & -7.83 & -10.45 & This paper \\
\hline Gubrist & Carbonate nodule & -8.08 & -8.70 & This paper \\
\hline Gubrist & Carbonate nodule & -8.18 & -6.79 & This paper \\
\hline Muttenz & Gravitational cement & -6.9 & -10 & Kock et al. (2009) \\
\hline Muttenz & Gravitational cement & -6.7 & -10.4 & Kock et al. (2009) \\
\hline Muttenz & Gravitational cement & -6.7 & -10.2 & Kock et al. (2009) \\
\hline Muttenz & Gravitational cement & -7.7 & -10.5 & Kock et al. (2009) \\
\hline Markhof & Gravitational cement & -8 & -10.8 & Kock et al. (2009) \\
\hline Markhof & Gravitational cement & -7 & -10.9 & Kock et al. (2009) \\
\hline Markhof & Gravitational cement & -7.2 & -11.1 & Kock et al. (2009) \\
\hline Markhof & Gravitational cement & -7.8 & -10.8 & Kock et al. (2009) \\
\hline Markhof & Gravitational cement & -8.1 & -10.8 & Kock et al. (2009) \\
\hline
\end{tabular}

We shall first discuss the stable isotope values of the realm with $\delta^{13} \mathrm{C}$ values smaller than $-9 \%$. The two isotope measurements from isopachous cement do correspond very closely to the tufa values and we thus conclude that both are pure precipitates from groundwater without any admixtures of foreign (detrital) carbon. The $\delta^{13} \mathrm{C}$ values from the gravitational cements given by Kock et al. (2009) are very similar but slightly more negative. Roughly, DIC in groundwater is derived from two sources: from the dissolution of organic carbon (from root respiration and oxidation of soil organic matter), and from the dissolution of inorganic carbon (from carbonate aquifer rocks). The former has highly negative $\delta^{13} \mathrm{C}$ values (around $-23 \%$ for soil in areas dominated by $\mathrm{C} 3$ plants, see Cerling, 1984) whereas the latter has $\delta^{13} \mathrm{C}$ around $0 \%$. The relative abundance of carbon from these two sources determines the $\delta^{13} \mathrm{C}$ composition of groundwater and hence also of calcite which precipitates out of it. Groundwater $\delta^{13} \mathrm{C}$ values thus often show a typical development: shallow groundwater (just leaving the soil zone rich in organic carbon) is highly depleted in ${ }^{13} \mathrm{C}$ but the ${ }^{13} \mathrm{C}$ content of deeper groundwater increases while the water is moving through an aquifer and constantly dissolves some carbonate thus shifting the $\delta^{13} \mathrm{C}$ value of the groundwater DIC towards less negative values (Fritz et al., 1976). Bearing this in mind, we interpret the slightly 
more negative $\delta^{13} \mathrm{C}$ values of the gravitational cement in Figure 7 as reflecting its more shallow and therefore more soil organic carbon influenced origin. The sparitic isopachous cement would reflect the slightly more positive $\delta^{13} \mathrm{C}$ values of deeper groundwater which contained more dissolved carbon stemming from aquifer carbonates. Despite the above mentioned theoretical difficulties (evaporation), the $\delta^{18} \mathrm{O}$ values of the gravitational cements (ranging from $-6.7 \%$ to $-8.1 \%$ VPDB) can readily be interpreted as the value of calcite precipitated from water with a temperature of $8.9^{\circ} \mathrm{C}$ (mean annual air temperature of a nearby measuring station of the Swiss Meteorological Survey, see www.meteoschweiz.admin.ch) and $\delta^{18} \mathrm{O}$ composition of $-8.4 \%$ to 9.8\% VSMOW (Vienna Standard Mean Ocean Water) using the formulae of Hays \& Grossman (1991). These values are in good agreement with the $\delta^{18} \mathrm{O}$ value of recent rain water in the area $(-9.3 \%$ o using the interpolations and values of adjacent measurement stations reported by Schürch et al., 2003) and suggest a similar climatic/hydrologic situation during the Late Pleistocene/Early Holocene and today. The $\delta^{18} \mathrm{O}$ values of the sparitic values are more difficult to interpret. Menzingen is near to the Alps and somewhat elevated (800 to 900 $\mathrm{m}$ above sea level). From the measured calcite $\delta^{18} \mathrm{O}$ values and a mean annual air temperature of $5.9{ }^{\circ} \mathrm{C}$ (Swiss Meteorological Survey) one would expect a groundwater $\delta^{18} \mathrm{O}$ composition of $-9.9 \%$ VSMOW. This contrasts to the interpolated precipitation $\delta^{18} \mathrm{O}$ value for this height (Schürch et al., 2003) of -10.5\% VSMOW. Thus, either these cements precipitated during a period warmer than the present (with less negative rain $\delta^{18} \mathrm{O}$ values), and/or from water which was considerably colder than modern groundwater.

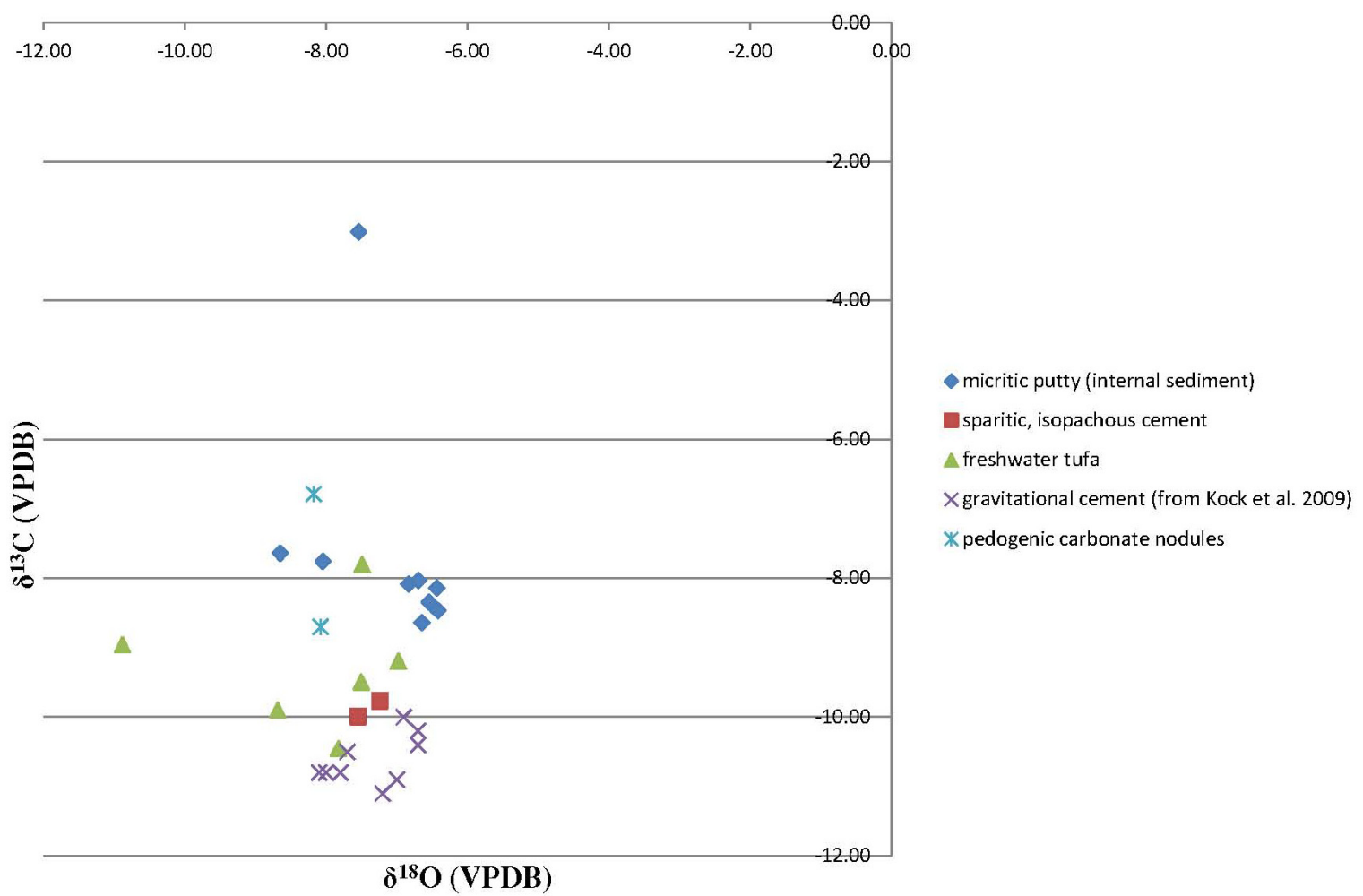

Figure 7. Stable isotope data

The second realm (i.e. with $\delta^{13} \mathrm{C}$ larger than $-9 \%$ ) contains samples which are expected to be mixtures of detrital carbonate and chemical groundwater precipitates. Hence, we choose another approach to explain the $\delta^{13} \mathrm{C}$ values. Following Letsch (2012), we assume that the micritic putty is a mixture of non-carbonate detritus, carbonate detritus, and carbonate cement. For the stable carbon isotope composition, the micritic putty $\left(\delta^{13} \mathrm{C}_{\mathrm{p}}\right)$ can be considered as a member of a mixing line with the two end-members carbonate detritus $\left(\delta^{13} \mathrm{C}_{\mathrm{is}}\right)$ and carbonate cement $\left(\delta^{13} \mathrm{C}_{\mathrm{c}}\right)$ :

$$
\delta^{13} \mathrm{C}_{\mathrm{p}}=\mathrm{x} \delta^{13} \mathrm{C}_{\mathrm{is}}+(1-\mathrm{x}) \delta^{13} \mathrm{C}_{\mathrm{c}}
$$

$\mathrm{x}$ denotes the relative abundance of carbonate detritus (internal sediment). From Figure 7 we deduce the following numeric values for the carbonate phases: $\delta^{13} C_{p}$ ranges from $-3 \%$ to $-9 \%, \delta^{13} C_{\text {is }}$ is assumed to be $0 \%$ o (rock flour derived from Alpine detritus which is mostly composed of marine carbonate rocks), and $\delta^{13} \mathrm{C}_{\mathrm{c}}$ is 
taken as $-10 \%$ (the value obtained for groundwater precipitated cements). We arrive at values for $\mathrm{x}$ ranging from 0.1 (i.e. $10 \%$ ) to 0.7 (i.e., $70 \%$ ), for the $\delta^{13} \mathrm{C}_{\text {sample }}$ values $-9 \%$ and $-3 \%$, respectively. This range seems quite plausible if one recalls the different appearances of the carbonate putty ranging from pure powder, over friable tufa-like masses, to hard, rock-like, micrite.

The assumption that most of the observed carbonate putty in the gravel pore space is a mixture of (glacial) detritus and later chemical precipitates, is additionally supported by the stable isotope signature of the two carbonate concretions from a till layer (Gubrist locality). There, the assumption of such a mixture is evident and the stable isotope signatures fall into the assumed mixing line for the carbonate putty.

Finally, we would like to point out that none of our samples showed strongly depleted $\delta^{18} \mathrm{O}$ values (smaller than $-20 \%$ ). Such values would be expected for chemical precipitates out of glacier meltwater which is depleted in ${ }^{18} \mathrm{O}$. Such precipitates may develop beneath the glacier, or in the surface sediments of glacial lakes (Fairchild \& Spiro, 1990). From the lack of such negative values, we conclude that all our samples analyzed for stable isotopes were not in contact with glacial meltwater when they were cemented. The observed $\delta^{18} \mathrm{O}$ values are more in accord with cement precipitation out of inter- or postglacial groundwater.

\section{Discussion}

\subsection{Genetic Models for the Origin of Putty Rich and/or Cemented Zones}

We have pointed out several lines of evidence which suggest that carbonate, filling some of the pore space of Quaterny gravel and so giving the latter cohesion ("cement"), is of diverse origin. Cements in the strict sense seem to be of minor importance. More often we encounter micritic putty which must have originated after deposition of the gravel skeleteon but which, nevertheless, exhibits characteristic of detrital sediment and which we therefore interpret as internal sediment which later became cemented. Now, we will sketch genetic models for the develoment of both, internal carbonate sediment (and its later cementation), and true chemical carbonate cements in Quaternary gravel. We feel that this genetic approach could be useful for predicting the spatial distribution of cemented and/or putty rich zones in gravel.

\subsubsection{Infiltration of Internal Sediment}

Due to mechanical abrasion of carbonate bedrock and subsequent particle comminution at the glacier base, the glacial is one of the few sedimentary environments that yields high amounts of extremely fine (fine silt to clay sized) carbonate and other detritus (rock flour, "glacier milk" if suspended). Hence it seems reasonable to assume that the source for the above proposed fine grained carbonate sediment which later became cemented to carbonate putty has to be sought in glacier meltwater (see also Schlüchter, 1976; Paxton \& Martin, 1980; and Graf, 1993). On modern gravelly glacier forfields, silty drapes deposited from suspension during waning floods on gravel bar tops can indeed be observed. However, no studies exist on the depth to which such fine material penetrates into the underlying gravel. In Figure 8 (A, B) we propose two schematic models to account for glacier milk infiltration into gravel. Figure 8A depicts an ice-marginal lake with a Gilbert-type delta. The figure can be used a an interpretational scheme for our sampling sites Küsnacht and Eschenberg-Chüeferbuck. Glacier milk infilatration will occur preferentially at more permeable (i.e., coarse grained and/or well sorted) zones of the gravel where meltwater can easily penetrate. The coarse grained topset layers (No. 1 in Figure 8A), and open-framework zones in the foreset layers (No. 2, cf. with Figure 2) will provide ideal candidates for glacier milk infiltration. Glacier milk which surpasses the proximal delta will finally flow into the lake where it will deposit its fine material either by means of turbidity currents, or simply through gradual settling out of the water column (Nr. 3). The micrite layers in the distal facies of the Küsnacht fossil delta complex (Figure 5B) are explained by this process. Figure $8 \mathrm{~B}$ depicts the situation of a "dry" glacier tongue with its gravel forefield. Glacier milk infiltration will be restricted to the the proximal zone of the glacier foreland.

\subsubsection{Cementation of Quaternary Gravel}

After having discussed the mechanism by which a substantial amount of very fine and probably chemically quite reactive (due to its large specific surface area and abundant lattice defects due to stresses experienced through the glacier, cf. Fairchild \& Spiro, 1990) carbonate detritus occupies the pore space of glacial gravel after deposition of the latter, we will discuss the modes by which cementation of these gravels can take place. Figure 8C schematically illustrates seven situations in which carbonate cementation in Quaternary gravel could be observed in the present study. It should be pointed out that cementation can and does also occur when no internal carbonate sediment is present. However, the occurence of the latter does greatly enhance the probability for later cementation as it provides readily available carbonate.

Calcite precipitation in the soil zone due to biogenic activity and/or evaporation (pedogenic carbonates, No. 1 in 
Figure $8 \mathrm{C}$ ) is a common process and by no means restricted to warm climatic zones (Strong et al., 1992). The calcite crusts found on pebble undersides in fluvial gravel are clear representatives for pedogenic carbonates as are the carbonate nodules grown in the till at the Gubrist locality. Depleted $\delta^{13} \mathrm{C}$ values further confirm the pedogenic origin of these cements. Genetically related to these near-surface cements are fine grained to sparitic crusts which overgrow gravel outcrops when exposed for some time (No. 2). The carbonate cement precipitates due to $\mathrm{CO}_{2}$ outgasing and evaporation when groundwater arrives at the surface where lower $\mathrm{CO}_{2}$ partial pressures persist than in the groundwater and the pore space of gravel. It is thus genetically related to freshwater tufa.

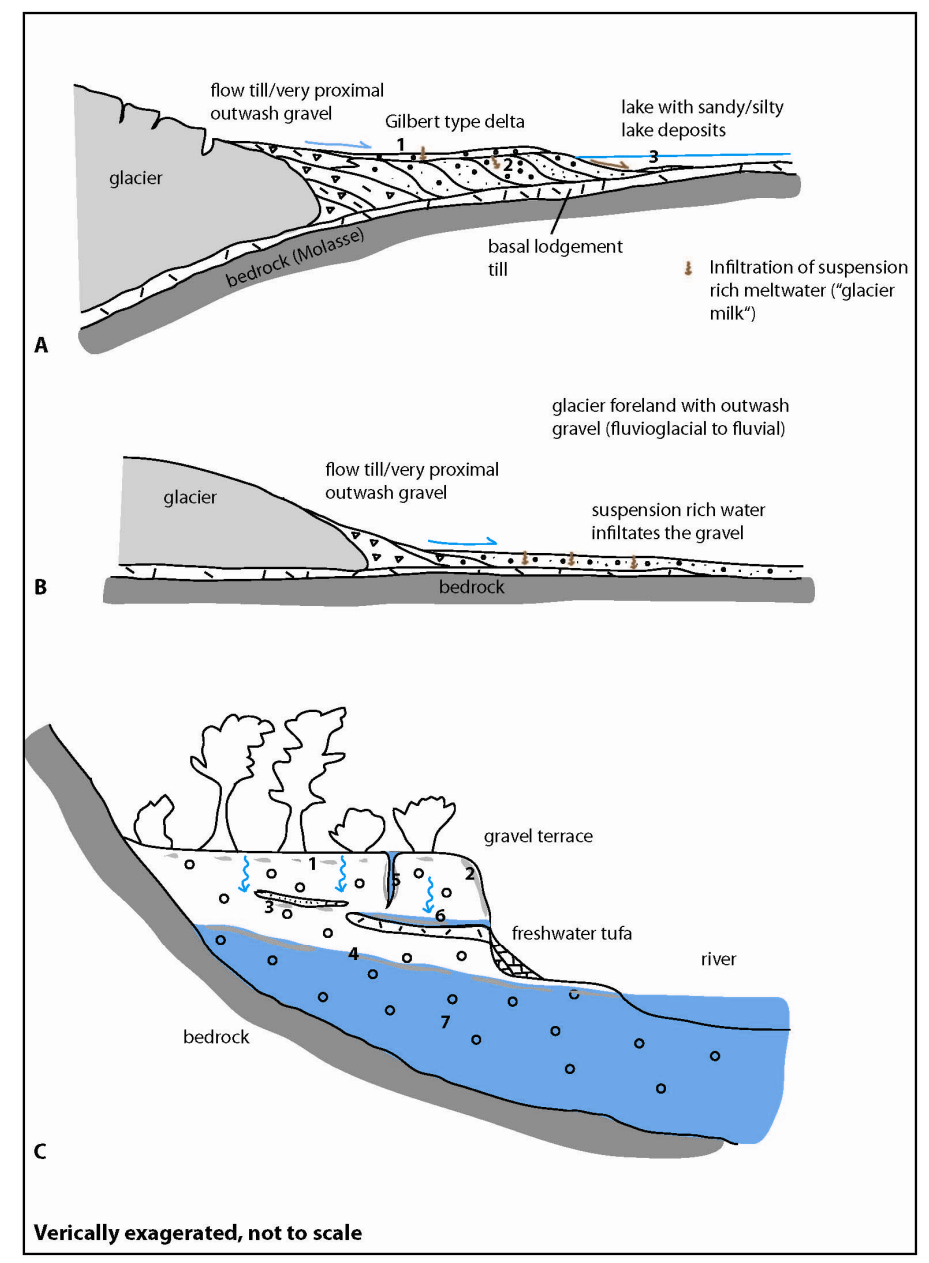

Figure 8. Genetic models to explain the infiltration of internal sediment into glacial gravel (A, B) and the development of carbonate cements (C). See text for explanation

In contrast to these two surface-bound modes of cement precipitation, we presented many cases where cementation occurred deeply inside a gravel body but well above the groundwater table (No. 3). We distinguish here two sub-modes. First, cementation may be distributed in a patchy ("cloudy") manner and is then determined by the original distribution of internal carbonate sediment. Later cementation was supposedly accomplished by vadose groundwater which trickled through the internal sediment and precipitated (and possibly also dissolved and re-precipitated) carbonate cement which hardened the originally soft internal sediment. That this cementation took place under rather warm (inter- or postglacial) conditions and not by participation of glacier-derived meltwater, but rather of ordinary groundwater, is shown by the $\delta^{18} \mathrm{O}$ values. The second sub-mode is cementation which is not necessarily dependant on pre-existing carbonate rock flour, but rather on local changes of sedimentary texture and hence permeability (Aber, 1979; Graf, 1993). Vadose groundwater leaving a low permeability layer will adjust to a new chemical microenvironment (e.g., to a different $\mathrm{CO}_{2}$ partial pressure) and may thus precipitate calcite (Elbracht, 2010). Such cement occurrences are rather small and quite difficult to predict as an idea about their spatial distribution would require a detailed knowledge about the local 
permeability patterns in the gravel body.

The three modes so far described are all restricted to the realm of vadose groundwater. We will now discuss modes in the phreatic realm. An obvious and often observed case is cementation at the groundwater table (No. 4). Genetically, two explanations for these cements can be envisaged. First, calcite precipitation can be induced by repeated evaporation in the range of the changing groundwater table. The cements thus precipitated should then strictly be considered as of vadose origin and will exhibit petrographic features typical for this mode of origin (meniscus and gravitational cements). The thickness of a gravel zone cemented by such a cement would then approximate the range of groundwater table oscillation during its precipitation. The second case is truly phreatic cementation just below the groundwater table, which can readily be explained by the process of "mixing precipitation" (Runnels, 1969): mixing of downward moving vadose water and the phreatic groundwater (with different ion concentrations and gas partial pressures) can either lead to calcite under- or supersaturation. If the latter happens to be the case, phreatic carbonate cement (isopachous and/or blocky sparitic) will precipitate. Similar precipitation processes leading to similar cements will presumably also be at work in local phreatic zones in otherwise vadose realms (modes Nos. 5 and 6). Calcite cementation in the phreatic realm but well below the groundwater table (No. 7) is probably due to at least two factors: availability of carbonate rock flour, and local changes of sediment texture. Thus, complex and hardly predictable cementation patterns (patchy, cloudy) of different cement/putty types have to be expected (as e.g., in the Küsnacht sampling site).

\subsection{Criteria to Dicriminate True Cement and Cemented Internal Sediment}

The distinction between true cements and cemented internal sediment (putty) is not only of academic but also of practical importance (prediction of spatial distribution of cemented zones). We thus shortly recapitulate some criteria of discrimination which we found to be useful.

Grain- or crystal-size is a straight forward criterion: whereas true chemical cements are often composed of calcite crystals considerably larger than $100 \mu \mathrm{m}$ and therefore recognizable by eye (Figure 6), glacier derived rock flour forming internal sediment is often much finer grained (few $\mu \mathrm{m}$ to sub- $\mu \mathrm{m}$ size). To distinguish individual grains one has to apply either scanning electron microscopy, or ultra-thin sections (Fairchild, 1983). However, as shown above, some vadose cements have crystals smaller than 100 microns and distinction from internal sediment from grain size considerations in thin-sections alone gets difficult. Additional criteria are then internal structure and spatial distribution of the cement/putty: coarser detrital layers, local grading, non-biogenic lamination, glacio-tectonic deformation structures, or infill structures are typical for internal sediments whereas vadose cements contain organic laminations and develop preferentially at pebble contacts and on pebble undersides. On a somewhat larger scale, internal sediment and cement show different distribution patterns relative to gravel texture. Whereas internal sediment preferentially develops in open framework gravel, pure cements do rather - but not exclusively - occur in gravel with substantial amounts of sand (as also noted by Aber, 1979).

Finally, if the above mentioned criteria fail to provide an unequivocal distinction, geochemical methods may help. The mineralogic composition of the cements/putty has not been treated in the present study, but it is a priori clear that internal sediment will contain also non-carbonate phases whereas true cements will be pure carbonates. A distinction between pure but very fine-grained cements and cemented internal sediment seems also possible on the basis of $\delta^{13} \mathrm{C}$ values. However, for this we need to know the isotopic end-member composition of pure chemical precipitates.

\section{Some Consequences for Pre-Quaternary Glacigenic Rocks}

Carbonates interbedded with unquestionable tillites and glacigenic conglomerates are a common feature of many pre-Quaternary (mostly Palaeozoic and older) glacigenic sections. These carbonates are of importance for several reasons. Their stable isotope signature can be used to distinguish glacio-marine from terrestrial tillites (Bhattacharya et al., 2002), or to reconstruct past glacial and interglacial climates. They also provide evidence for past glaciations in low latitudes and they - among other evidence - led to the proposal of the "Snowball Earth" theory. Without going into much detail, we would finally like to mention some points concerning such carbonates which we deduced from our study of much younger and thus more readily interpretable carbonates in glacigenic rocks.

First, very fine grained carbonates in glacigenic sediments need not to be necessarily true cements, i.e. chemical precipitates. We could demonstrate the occurrence of micritic carbonates which are of detrital origin and which either occur in the pore space of glacial gravel or as layers in sandy lake deposits. Fairchild \& Spiro (1990) described analogous deposits from a Late Proterozoic section in Spitsbergen. Based on petrographic and geochemical data, they postulated an early diagenetic wholesale recrystallization of the fine and chemically very 
reactive detrital carbonate mud and pointed out its potential for paleoenvironmental analysis (proxy for isotopic composition of glacier meltwater). The detrital carbonates described in this paper would probably provide useful young analogues to study the reality and timing of such early recrystallizations and could thus help to better appreciate the value of fine grained clastic carbonates in ancient glacigenic rocks as paleoenvironment archives.

Second, we deduced that these originally soft and plastic (glacial deformation) carbonates were later cemented by groundwater whose isotopic composition resembles the composition of recent groundwater. Thus, cementation (and recrystallization?) of this fine detritus took presumably place during warm interglacial phases and we can therefore derive no information on the isotopic composition of glacial meltwater from them. They rather record the groundwater composition of the warmer phases which interrupted the glaciations. Anyway, in order to derive these water compositions, one needs to know both the temperature of calcite precipitation and the amount and isotopic composition of the detrital carbonate component. We thus see a rather limited paleoclimatic potential of these detrital carbonates.

Third, true early diagenetic cements do occur in glacial gravel but we could not find any indication that they developed already during cold phases beneath the glacier as suggested by Schmidt and Friedman (1974) for analogous early (pre burial diagenetic) cements in Permo-Carboniferous glacigenic rocks in Antarctica. Thus, as it was the case for the cemented detrital carbonates, stable isotopes of true cement in glacial gravel and tills probably record inter- or postglacial isotopic signals rather than glacial ones. Their use as an abundantly available paleoclimate archive seems nevertheless promising.

Finally, from our finding that most carbonate cements and concretions in glacigenic deposits develop after glaciation during phases more favorable to calcite precipitation, we cast some doubt on the approaches of Schmidt and Friedman (1974) and Bhattacharya et al. (2002) to use the stable isotope signatures of cement and concretions to distinguish between terrestrial and marine glacigenic rocks.

\section{Acknowledgements}

T. Blattmann (ETH Zurich), M. Freimoser, H. R. Graf, U. Jörin, A. Wildberger (all from von Moos consulting company), and P. Haldimann (Jäckli consulting company), are to be thanked for many useful discussions. T. Blattmann and L. Wüthrich (University of Berne) helped in the field and H. Weissert (ETH Zurich) organized some of the stable isotope measurements.

\section{References}

Aber, J. S. (1979). Glacial conglomerates of the Appalachian Plateau, New York. Quaternary Research, 11, 185-196. http://dx.doi.org/10.1016/0033-5894(79)90003-6

Andrews, J. E., Riding, R., \& Dennis, P. F. (1993). Stable isotopic compositions of Recent freshwater cyanobacterial carbonates from the British Isles: local and regional environmental controls. Sedimentology, 40, 303-314. http://dx.doi.org/10.1111/j.1365-3091.1993.tb01765.x

Bhattacharya, S. K., Gosh, P., \& Chakrabarti, A. (2002). Isotopic analysis of Permo-Carboniferous Talchir sediments from East-Central India: signature of glacial melt-water lakes. Chemical Geology, 188, $261-274$. http://dx.doi.org/10.1016/s0009-2541(02)00140-7

Cerling, T. E. (1984). The stable isotopic evolution of modern soil carbonate and its relationship to climate. Earth and Planetary Science Letters, 71, 229-240. http://dx.doi.org/10.1016/0012-821x(84)90089-x

Dunham, R. J. (1969). Early vadose silt in Townsend mound (reef), New Mexico. In G. M. Friedman (Ed.), Depositional environments in carbonate rocks (pp. 139-181). Society of Economic Paleontologists and Mineralogists Special Publication No. 14.

Dunham, R. J. (1971). Meniscus cement. In O. P. Bricker (Ed.), Carbonate cements (pp. 297-300). Baltimore: The Johns Hopkins Press.

Elbracht, J. (2010). Karbonatische Zementation pleistozäner Lockersedimente Nordwest-Deutschlands. Geologisches Jahrbuch Sonderhefte Reihe A, Heft SA2, 3-225.

Fairchild, I. J. (1983). Effects of glacial transport and neomorphism on Precambrian dolomite crystal sizes. Nature, 304, 714-716. http://dx.doi.org/10.1038/304714a0

Fairchild, I. J., \& Spiro, B. (1990). Carbonate minerals in glacial sediments: geochemical clues to palaeoenvironment. In J. A. Dowdeswell, \& J. D. Scourse (Eds.), Glacimarine Environments: Process and Sediments (pp. 201-216). Geological Society Special Publication No. 53.

Fairchild, I. J., Bradby, L., \& Spiro, B. (1994). Reactive carbonate in glacial systems: a preliminary synthesis of 
its creation, dissolution and reincarnation. In M. Denoux et al. (Eds.), Earth's glacial record (pp. 175-192). Cambridge: University Press. http://dx.doi.org/10.1017/CBO9780511628900.014

Fritz, P., Reardon, E. J., Baker, J., Brown, R. M., Cherry, J. A., Killey, R. W. D., \& McNaughton, D. (1978). The carbon-isotope geochemistry of small groundwater systems in Northeastern Ontario. Water Resources Research, 14, 1059-1067. http://dx.doi.org/10.1029/wr014i006p01059

Graf, H. R. (1993). Die Deckenschotter der zentralen Nordschweiz (Doctor thesis). ETH Zurich.

Graf, H. R. (2009). Stratigraphie von Mittel-und Spätpleistozän in der Nordschweiz. Contributions to the Geological Map of Switzerland, 168, 1-198.

Hays, P. D., \& Grossman, E. L. (1991). Oxygen isotopes in meteoric calcite cements as indicators of continental paleoclimate. Geology, 19(5), 441-444. http://dx.doi.org/10.1130/0091-7613(1991)019\%3C0441:oiimcc\%3E2.3.co;2

Knight, J. (1998). Origin and significance of calcareous concretions within glacial outwash in the Tempo Valley, north-central Ireland. Boreas, 27, 81-87. http://dx.doi.org/10.1111/j.1502-3885.1998.tb00869.x

Kock, S., Kramers, J. D., Preusser, F., \& Wetzel, A. (2009). Dating of Late Pleistocene terrace deposits of the River Rhine using uranium series and luminescence methods: potential and limitations. Quaternary Geochronology, 4, 363-373. http://dx.doi.org/10.1016/j.quageo.2009.04.002

Letsch, D. (2012). Deutungsversuch einer komplexen eisrandnahen Talfüllung: die Wulp-Schotter und ihr glaziales Umfeld. Swiss Bulletin for Applied Geology, 17(1), 61-76.

Longo, W. (1978). Geologie des Hagenholztunnels bei Kloten. Eclogae geologicae Helvetiae, 71(1), 175-182.

Müller, G. (1971). "Gravitational" cement: an indicator for the vadose zone of the subaerial diagenetic environment. In O. P. Bricker (Ed.), Carbonate cements (pp. 301-302). Baltimore: The Johns Hopkins Press.

Paxton, S. T., \& Martin, W. D. (1980). Petrography and diagenetic evolution of cements in some Pleistocene glaciofluvial deposits from S. W. Ohio, S. E. Indiana, and N. Kentucky. Ohio Journal of Science, 80, 34.

Runnels, D. D. (1969). Diagenesis, chemical sediment, and the mixing of natural waters. Journal of Sedimentary Petrology, 39, 1188-1201. http://dx.doi.org/10.1306/74D71DCA-2B21-11D7-8648000102C1865D

Schlüchter, C. (1976). Geologische Untersuchungen im Quartär des Aaretals südlich von Bern. Contributions to the Geological Map of Switzerland, 148, 1-117.

Schmidt, D. L., \& Friedman, I. (1974). Continental deposition of Antarctic tillite indicated by carbon and oxygen isotopes. Journal Research U.S. Geological Survey, 2(6), 711-715.

Schürch, M., Kozel, R., Schotterer, U., \& Tripet, J. P. (2003). Observation of isotopes in the water cycle-the Swiss National Network (NISOT). Environmental Geology, 45(1), 1-11. http://dx.doi.org/10.1007/s00254-003-0843-9

Selleck, B., \& Baran, J. (2003). Petrology and stable isotope geochemistry of Pleistocene and Holocene calcite cement in kame terrace gravel, Central New York State. Northeastern Geology and Environmental Sciences, 25(3), 186-196.

Strong, G. E., Giles, J. R. A., \& Wright, V. P. (1992). A Holocene calcrete from North Yorkshire, England: implications for interpreting palaeoclimates using calcretes. Sedimentology, 39, 333-347. http://dx.doi.org/10.1111/j.1365-3091.1992.tb01042.x

Swett, K. (1974). Calcrete crusts in an arctic permafrost environment. American Journal of Science, 274, 1059-1063. http://dx.doi.org/10.2475/ajs.274.9.1059

\section{Copyrights}

Copyright for this article is retained by the author(s), with first publication rights granted to the journal.

This is an open-access article distributed under the terms and conditions of the Creative Commons Attribution license (http://creativecommons.org/licenses/by/3.0/). 